\title{
Humanisten mellem Kierkegaard og Marx - Villy Sørensens filosofi
}

\section{Demokratiet, mennesket og personligheden}

'Åndsarbejderne' har - erklærende Villy Sørensen i en diskussion i 1960 - afskediget 'mellemkrigstidens krævende Enten-Eller til fordel for et lige så krævende Hverken-Eller', hvormed han samtidig sprogligt angav den afgørende side af forskydningen: hvor mellemkrigstidens og den kolde krigs krav kom fra de forskellige grupper, et krav om at tage stilling altså et krav udefra, så er det åndsarbejderen selv der stiller kravet 'Hverken-Eller', som er et krav til personligheden selv, ikke et krav om at stille personen ind i et geled. Kravet til personen, hver enkelt person, om at udvikle sin personlighed er overhovedet det centrale tema i Villy Sørensens filosofi, ligesom det er den for ham (som for Poul Henningsen) at se fundamentale forudsætning for fastholdelsen og udviklingen af 'demokratiet'. Han har selv karakteriseret sin baggrund således:

'Hvad protesten dengang gjaldt, var først og fremmest tendensen til at sætte folk i bås (det var endnu McCarthy-tid), til ikke at skælde en mand ud for det han mener, men for det en gruppe mener, som han måske ikke en gang hører til og som måske ikke engang eksisterer. Dengang tav man muligvis stille for ikke at blive taget til indtægt af de forkerte, nu taler man muligvis højt for at opløse de forældede frontholdninger og kunstige skillelinjer [...].' (FF s. 17, ovenstående citat fra HE s. 105)

På denne baggrund søger han at fremme 'den saglighed, der kun er polemisk vendt mod de ensidige' (HE s. 29). Denne saglighed er fornøden $i$ en situation, hvor 'den almindelige [...] værdiopløsning har til følge at de forskellige værdiområder afgrænser sig mod hinanden, bliver selvtilstrækkelige og abstrakte [...]' (DD s. 233), hvilket igen ikke mindst hænger sammen med at "Fremskridtet" jo især [har] ytret sig som en fremadskridende specialisering [...]' (HE s. 9).

Heraf den manglende sammenhæng:

'Den moderne kontaktløshed mennesker imellem beror, som næunt, på at alle er en slags fagmænd der kun kan overskue deres 
eget fag og undertiden knap nok det.' (HE s. 21) Under disse omstændigheder mangler 'demokratiet' et fælles grundlag, der kan skabe sammenhæng og meningsoverensstemmelse, 'Demokratiets problem - dets grundproblem siger Tingsten - er manglen på det værdifællesskab, som det forudsætter, men ikke uden videre medfører [...]' (FF s. 195). Og er værditraditionen blevet brudt, må der søges 'en dybere sammenhæng end traditionen' (FF s. 14)

Villy Sørensens grundproblem er således at opspore og virke for en værdisammenhæng, som ikke umiddelbrt er for hånden, men som er en nødvendighed for 'demokratiet'. Hele hans kritiske forfatterskab kan ses som en eftersøgning af et sådant værdigrundlag (det gælder i øvrigt ikke mindst for Uden mål - og med, som ikke skal tages op her, da den ligger efter 1968, men det gælder også de tidligere bøger, som skal diskuteres i det følgende). Kilder søger han $\mathrm{i}$ det moderne åndsliv, det filosofiske og det kunstneriske, men ikke i det moderne samfundsliv.

I sin første bog sætter han af fra Hegel, dvs. han tager sit udgangspunkt i de to kritiske opgør med Hegel, som repræsenteres af Kierkegaard og Marx. Hegel var den sidste universalist og hans filosofi blev til legitimationsfilosofi for en autoritær stat. Det negative, som var drivkraften i hans kritiske filosofi (i Logikken) trådte $\mathrm{i}$ baggrunden (i Retsfilosofien), fra udgangspunktet $\mathrm{i}$ revolutionen i Frankrig kom han til slutpunktet i reaktionen i Preussen. Men hans filosofi gav stødet til to typer kritik. Kierkegaards, som vendte sig imod indordningen af individet som moment i den formidlede totalitet, og Marx', som vendte sig imod harmoniseringen, dialektikkens stilstand. Hvor Kierkegaard nåede frem til at insistere på den enkelte, der nåede Marx frem til at insistere på klassekampen, det bliver for Villy Sørensen til:

'Kierkegaard gik ud fra det problematiske i personligheden, Marx fra det problematiske i samfundet.' (DD s. 8) Og det bliver ejendommeligt nok, men ikke så mærkeligt, når Villy Sørensens filosofi tages i betragtning, til at begge gik ud fra den enkelte, Kierkegaard fra den enkeltes problemer med sig selv, Marx fra den enkeltes problemer med samfundet. Kierkegaard bliver således repræsentant for 'det indre', mens Marx bliver repræsentant for 'det ydre'. Det er derfor logisk - som Villy Sørensen selv ville sige - at den Marx der kommer på tale er den unge Marx (det var overhovedet fortrinsvis ham, der var på tale blandt ikke-kommunistiske intellektuelle dengang, når de da talte om Marx): 'Marx [løste] den besynderlige modsigelse: at det frie menneske skaber en verden, 
hvori mennesket ikke er frit, ved hjælp af begrebet 'fremmedgørelse', et begreb som hele Marx' filosofi (men ikke hans forskellilge økonomiske teorier) står og falder med.' (FF s. 144, jeg har flyttet lidt rundt på citatets forskellige dele, men det ændrer ikke meningen). Ved at holde sig - mere eller mindre nært - til den unge Marx, holder Villy Sørensen sig samtidig på afstand af analysen af det kapitalistiske samfund, med det resultat, at han med sin intellektuele hæderlighed nogenlunde i behold kan fortsætte med at tale om Mennesket uden at tale om klasser. Ikke fordi Villy Sørensen ikke flere gange kommer ind på også den senere Marx, men det kommer aldrig til at spille nogen rolle for hans tankegange.

Både Kierkegaard og Marx anses for utilstrækkelige, den første fordi han ser bort fra de samfundsmæssige forholds betydning, den sidste - eller i hvert fald hans efterfølgere - fordi de psykiske forhold ikke tages i betragtning. Villy Sørensens projekt er nu at korrigere den ene med den anden, men det sker fortrinsvis ved abstrakte henvisninger, som refereret $\mathrm{i}$ den foregående sætning, eller ved analogier og underordning af begge filogofier under fælles tredje begreber, nemlig ikke mindst hans egne. Således bliver de samfundsmæssige problemer, som jo er klassemodsætninger - også i Marx' ungdomsskrifter -, til 'de sociale traumer', eller samfundet bliver ligefrem til et 'traume':

'Marx selv interesserede sig kun lidt for fremtidsstaten, for ham var samfundet, som det foreløbig var, det traume som skulle fjernes.' (Dd s. 207-8)

De problemer, som optog Kierkegaaard, blev også taget op af psykoanalysen, som 'arbejder på at fjerne de psykiske traumer, der forhindrer menneskene i at være sig selv' (s. 208). Både hos Marx og hos psykoanalytikerne (og hos Kierkegaard) finder Villy Sørensen således en teroi om 'afvigelsen', og derfra kan han så gå videre dels med at påvise, at den ene teori må suppleres og korrigeres med den anden, dels med at gennemføre en række paralleller.

\section{Frihed og tilpasning}

Sandhed er for Kierkegaard 'ikke først og fremmest overenstemmelse mellem tanke og virkelighed, men meneskets overensstemmelse med sig selv', og menneskets evne til at blive sig selv afhænger kun af ' - det selv. Hvor det gælder at 'realisere sig selv' har alle mennesker, alle psykiske og sociale forskelle til trods, lige gode 
forudsætninger [...]' (FF s. 104-5).

Ganske vist kan mennesket aldrig helt blive sig selv og derfor heller aldrig komme 'helt ud over angsten og fortvivlelsen' (s. 106), men den rette eksistentielle holdning ligger i dette hele tiden at have 'sig selv som problem' (105). Det er imidlertid lige præcis det 'folk' ikke bryder sig om, 'det som folk allernødigst vil, er at vide noget om sig selv' (BA s. 8). Det er i dette brydningspunkt Villy Sørensens optagethed af Kierkegaard skal søges for så vidt angår den principielle diskussion, som forfølges her. Modsætningen til at vide noget om sig selv, at have sig selv som problem, er at hengive sig til den forhåndenværende mest bekvemme bestemmelse af sig selv, en bestemmelse som da kommer udefra, fra konventioner, fra das Man, som Villy Sørensen gentagne gange citerer Heidegger for. Og det vil politisk sige, at man ikke i den demokratiske proces og i den samfundsmæssige sammenhæng har noget at sætte op imod de ydre påvirkninger. Ikke at have sig selv og sin personligheds udvikling som problem, det er ensbetydende med at opgive friheden. Kierkegaards religiøst begrundede analyse taler om synd og om frihed som syndens forudsætning, men Villy Sørensen overtager problematikken og anvender den på det moderne velfærdssamfunds liv:

'I disse ukristelige tider er det vel de færreste der oplever et 'syndefald' i deres eget liv. Derimod oplever de fleste, netop i disse ukristelige tider, det, som Kierkegaard anså for den psykologiske følge af syndefaldet: splittelsen i selvet, den absurde oplevelse af at være fremmed for sig selv (den oplevelse, der synes at ligge til grund for så megen moderne kunst).' (BA s. 15).

Disse oplevelser har deres grundlag:

'[...] ser vi på følgerne af syndefaldet: at mennesket bliver sig sin seksualitet bevidst og i sin refleksion begynder at drage det i tvivl, som det hidtil har taget for givet, - så falder det naturligt at henlægge det til puberteten.' (BA s. 19)

Men dermed synes hele problemet at være biologisk betinget, hvilket gør det vanskeligt at forbinde med spørgsmålet om frihed. Dette problem løser Villy Sørensen under henvisning til, at 'det tilkommer mennesket selv at fortolke hvad det oplever. Frihed vil jo ikke sige, at man kan gøre akkurat hvad man vil på trods af de givne indre og ydre betingelser - det ville netop ikke være frihed, men trods - men at man kan fortolke dem som noget selvvillet eller selvforskyndt.' (BA s. 20)

Med denne formulering angiver Villy Sørensen - ved hjælp af 
ordspillet på 'trods' - en retfærdiggørelse af alt forhåndenværende: frihed er ikke betinget af forandringer, kun af forandrede fortolkninger, fri er man, når ufriheden er tolket som selvforskyldt. Villy Sørensen bliver da heller ikke stående på dette, men først tages det alligevel som udgangspunkt for kritik af 'det store publikum':

'Den, som er meget godt tilfreds med sig selv, oplever ingen splittelse i selvet. Den som føler sig i uoverensstemmelse med sig selv - og denne følelse er netop angsten - vil også føle sig stillet over for den opgave: helt at blive sig selv, blive 'ånd'. Ligesom der er en forbindelse mellem synd og frihed, er der altså også en forbindelse mellem ånd og disharmoni. Derfor ligger det så nær for de selvtilfredse positivister og for det store publikum af ånd-løse at afvise alt det, digtere og filosoffer skriver om angst og skyld [...]. Hvoraf kommer det, at det gerne er de mest værdifulde værker, der forekommer mest ubehagelige - [...] Det kunne jo skyldes, at der udgår et krav fra værkerne, som de [dvs. dem, der anser sig selv for sunde] dog ikke kan sidde overhørig, fordi de mærker det et eller andet sted i sig selv, måske netop der, hvor selvet skulle være -? (BA s. 21-2)

Formlen 'angsten for ånden' (s. 22) kan således benyttes til meget: til forklaring på det moderne åndslivs isolation og til forklaring på 'den enkeltes skrøbeligheder' (smst.).

Konklusionen på gennemgangen af Kierkegaards analyse af angsten bliver da:

'Gør vi de ydre faktorer, alle dem som videnskaben kan konstatere, til årsag, er det fordi vi selv vil - og fordi vi ikke vil kendes ved os selv; er vi ikke frie, er det fordi vi ikke vil, - og ikke at ville være sig selv, det er netop synden.' (s. 23)

Men dette er jo klart nok en tilpasningsfilogofi, som Villy Sørensen da heller ikke vil stå ved:

'Man kan naturligvis blive ved at diskutere, om den dogmatiske forudsætning for denne frihedsfilosofi ikke også er et fromt ønske, og om Kierkegaard, der fortolker alt indef ra, ikke er lige så ensidig som sine - hegelsk-marxistiske og positivistiske - modstandere, der forklarer alt udefra.' (smst.)

Heri ligger jo ingen som helst filosofisk eller anden form for bearbejdning af problemet, kun en markering af 'ensidighed'. Men Villy Sørensens næste skrift var et forord til et udvalg af Marx' ungdomsskrifter, som formentlig skulle ophæve ensidigheden. 


\section{En indre stum almindelighed}

Ligesom det var Kierkegaard om at gøre, at den enkelte skulle blive sig selv således 'protesterede marxisterne mod de faktiske sociale forhold, fordi de - efter deres opfattelse - forhindrede størstedelen af medmenneskene i frit at udvikle deres personlighed' (BA s. 11). Mens Kierkegaard protesterede imod Hegels indordning af de enkelte som momenter i den historiske udvikling, så protesterede Marx imod den faktiske reduktion af 'størstedelen af medmenneskene' til 'blot upersonlige redskaber for herskerklassen'. Og hvor Kierkegaard så friheden $\mathrm{i}$ at vende sig imod sig selv og realisere sig selv $\mathrm{i}$ inderlighed, der bestod 'størstedelen af medmenneskene's frihed for Marx i at de gjorde sig til 'redskab for udviklingen ved at arbejde for den sociale revolution', hvilket i øvrigt på hegelsk vil være ensbetydende med at gøre sig til bevidst moment $\mathrm{i}$ den historiske udvikling (og det er den tankegang Lukács udvikler i Historie og klassebevidsthed). Men dette sidste er faldet bort hos Villy Sørensen, som fastholder, at den historiske udvikling ifølge Marx forløber 'med streng nødvendighed', og insisterer på, at 'det marxistiske system har - lige så lidt som det hegelske - plads for den enkelte og hans indsats'. Men alligevel: 'for at være i pagt med udviklingen må man gå ind $\mathrm{i}$ den kollektive bevægelse: at være 'subjektiv' er at være bagstræver, og følelser som angst, fortvivlelse, skyld kan kun opkomme hos dem, der stamper imod brodden [...]' (BA s. 12)

Den sidste pasage er meget interessant, idet den implicit fastslår, at 'den enkelte og hans indsats' ikke kan forbindes med 'den kollektive bevægelse'. Men det kan der ikke findes belæg for hos Marx, og hans praksis bestod jo netop $i$ at gøre en indsats, som kunne hjælpe den kollektive bevægelse, ligesom han ved flere lejligheder deltog i den organiserede bevægelse. For at kunne hævde såvel Kierkegaards som Marx' 'ensidighed' og derefter benytte den ene som korrektiv for den anden, er Villy Sørensen nødt til at forkorte Marx. Gang på gang sker der da også en glidende overgang imellem Marx og en eller anden koldkrigskommunistisk tankegang, som derefter kritiseres. Til tider gør Villy Sørensen dog selv opmærksom på glidningen, ikke mindst når han kritiserer sovjetkommunismen for at være dårlig marxisme (som f.eks. FF $130,141-48$ ).

Den strenge nødvendighed i den historiske udvikling gør sig gældende så længe der ikke sker bevidste indgreb i forhold til den, hvad enten det er fra 'velfærdsstatens' eller det er fra 
arbejderklassens side, det var forudsætningen for Marx' politiske virke at fastholde dette teoretisk. Men det betyder ikke at den kapitalistiske økonomis lovmæssigheder kan ophæves uden ophævelse af kapitalismen, de kan kun modificeres i deres gennemslagsform, ligesom man kan modificere tyngdekraftens virkning ved at holde et faldefærdigt hus oppe med støttepiller uden at man dog derved ophæver tyngdekraften.

Der er således for Marx hverken tale om, at 'den enkelte og hans indsats' ingen plads har, eller tale om, at den kollektive bevægelses politiske indsats ingen rolle spiller for den historiske udviklings forløb. Når Villy Sørensen på disse to punkter misforstår Marx, så hænger det antagelig sammen med koldkrigsbaggrunden og den dogmatiserede marxismes (marxismen - leninismens) læresætninger på den ene side og anti-kommunismens dogmer om marxismen på den anden side, men det hænger nok også sammen med, at Villy Sørensens filosoferende tankeform har behov for overskuelige principielle modsætninger og problemer. I hans skrifter skrumper Marx' tanker og analyser ind til ganske få filosofiske principper, som derefter indoptages i de sørensenske begreber, som når Marx' fremmedgørelsesfilosofi gøres til en variant af den samme syndefaldsmodel, som Villy Sørensen fandt hos Kierkegaaard: 'Fremmedgørelsen er da Marx' udgave af syndefaldet, hvis indebyrd er at mennesket adskilles fra sit eget væsen, fra sit selv, blot skyldes faldet ikke mennesket selv og er altså ikke et syndefald, det sker af sig selv.' (ØF s. 18)

Marx's manuskripter om økonomi og filosofi er både stedvis kryptiske og præget af brydninger imellem de forskellige inspirationer, der ligger bag. Villy Sørensen kan finde belæg for f.eks. at 'arbejderens virksomhed [...] er hans selvs fortabelse' (s. 55), for så vidt er hans brug af Marx' ungdomsskrifter i overensstemmelse med Marx. Men samtidig repræsenterer denne brug en accentuering af $d e$ sider af manuskripterne, som i ringest grad peger fremad i retning af Marx' senere analyser. Når Marx skriver om menneskets væsen eller væsenskræfter, eller om artens væsenskræfter, så vil det sige menneskeartens historisk udviklede kreative formåen, som er nedlagt $\mathrm{i}$ de produktionsmidler, som træder op over for arbejderne som en selvstændig magt, ligesom varernes indbyrdes bevægelser antager selvstændig karakter, en selvstændighed som koncentreres i pengene. Pengene giver rådighed over resultaterne af de kreative muligheders udfoldelse og over disse muligheder selv, herunder arbejdskraften (som i 
ungdomsskrifterne blot omtales som arbejde). Men Villy Sørensen foretrækker at se disse væsenskræfter som menneskets væsen for derefter at interessere sig for det enkelte menneske, der er adskilt fra sit væsen, fra sit selv. Herigennem kan han etablere en formuleringsmæssige parallel til Kierkegaards problematik angående den enkelte, der skal blive sig selv.

På samme måde rejser der sig problemer i forbindelse med spørgsmålet om forholdet mellem dette væsen, som er frarøvet mennesket af de samfundsmæssige forhold, og Marx' bemærkning om, at menneskets væsen er 'indbegrebet af samfundsforholdene'. Ved at skrive sådan havner Marx i en selvmodsigelse, mener Villy Sørensen, eftersom det netop er 'samfundsforholdene, der forhindrer mennesket $i$ at udfolde sig efter sit voesen' (s. 115). Men Marx skriver sådan:

'Feuerbach opløser det religiøse væsen i det menneskelige væsen. Men det menneskelige væsen er ikke noget abstraktum, det enkelte individ iboende. I sin virkelighed er det indbegrebet af samfundsforholdene. Feuerbach, der ikke går ind på kritikken af dette virkelige væsen, er derfor tvunget til:

1. at abstrahere fra det historiske forløb og fastholde det religiøse sind for sig, og at forudsætte et abstrakt - isoleret - menneskeligt individ;

2. af den grund kan det menneskelige væsen hos ham kun opfattes som 'art', som en indre stum almindelighed, der blot med naturbånd forbinder de mange individer.' (ØF s. 92)

Det er nøjagtigt det samme Villy Sørensen gang på gang gør, og det gøres sprogligt ved hele tiden at tale om 'mennesket' med to vekslende betydninger, dels hvert enkelt individ, dels menneskene, hvad enten det er menneskeheden eller et samfund. Selv om Marx' ungdomsskrifter ikke netop er klare i deres samfundsanalyse, så kunne Villy Sørensen godt have undgået denne forkortning $\mathrm{i}$ og med sit kendskab til Marx' senere skrifter. Men i stedet er det problematikken fra ungdomsskrifterne, der bliver ført med over i læsningen af Kapitalen, hvor det udelukkende er omvendingen mellem subjekt og objekt, hvor kapitalen bliver selvstændigt 'subjekt', mens 'menneskene' reduceredes til 'objekter', der trækkes frem:

'Ud fra denne opfattelse kunne Marx konsekvent i sit hovedværk gøre kapitalen til hovedperson og mennesket til upersonlige funktioner af den. Men ud fra denne opfattelse er det også konsekvent, at skal kapitalens herredømme ikke vare evigt, må det 
sprænges indefra - af kapitalen selv. Marx' udviklingsprincip var stadig det hegelske: negationens negation, hos ham blot i en mere brutal udgave: med ondt skal ondt fordrives!' (s. 18-19)

Her røber Villy Sørensen ikke, at 'negationens negation' hos Marx er de udbyttedes bemægtigen sig deres egne produkter, altså produktionsmidlerne, dvs. en socialistisk revolution. Heller ikke om de indre modsigelsers karakter skriver han, end ikke om klassemodsætningen mellem kapital og arbejde. Det er kun den allermest filosofiske syntese, der har Villy Sørensens interesse. Derfor făr han heller intet greb om Marx' analyse af de samfundsmæssige bånd, som er det virkelige modstykke til de 'naturbånd', som den spekulative Feuerbach holdt sig til.

Ligesom i sin introduktion til Kierkegaards Begrebet Angst har Villy Sørensen i sin introduktion til Marx' ungdomsskrifter en afsluttende ophævelse af ensidigheden, idet han fremhæver, at selv om friheden i 'det ydre' er tilkæmpet, så 'bliver den dog ikke ved at bestå af sig selv', eftersom den beror på mennesket selv - 'på at det har et selv'. Og dermed er diskussionen om Kierkegaard inde $\mathrm{i}$ billedet igen, eftersom spørgsmålet om at have et selv og være sig selv netop var hans anliggende:

'Universelt udviklende produktionskræfter kræver ikke mindre arbejdsdeling end knap så udviklede, og skal arbejdsdelingen, der oprindelig indtrådte ufrivilligt og naturgivet, afløses af en frivillig og menneskelig, så forudsætter det netop, at frihed ikke blot er noget, der gives i det ydre, men at friheden - når den er givet - ikke tages for givet, som en ret, men stadig må skabes i det indre, som en indre fylde.' (ØF s. 24)

'Den Marx'ske filosofi, hvis udgangspunkt var friheden, står og falder med det frie menneske. Falder mennesket, når det ikke behøver falde, falder marxismen også - som andet og mere end en historisk betinget økonomisk teori.' (smst.)

Hvad end Villy Sørensen måtte mene med dette fald, så er det indlysende, at friheden i et socialistisk samfund hænger afgørende sammen med organiseringen af samfundslivet på alle planer, det afgørende kan derfor ikke være om hver enkelt 'falder', men om samfundsmedlemmerne undgår at falde fra hinanden, at de forbliver indbyrdes forbundne og udvikler båndene imellem sig. Hvad der er behov for, er ikke frihed som indre stum almindelighed eller som indre fylde, men frihed som fallesskab. Dette stiller sig imidlertid ikke som problem for Villy Sørensen, kun den enkelte og Mennesket, og det skyldes igen, at han forholder sig filosoferende til 
problemerne, ikke politisk.

\section{Det ydre og det indre}

Det samme gør sig galdende $\mathrm{i}$ de talrige bemærkninger og ræsonnementer omkring 'det indre' og 'det ydre', eksempelvis omtales Vietnam-krigen på denne måde:

'[...] det vestlige menneske har haft for vane at udkæmpe sine indre konflikter uden for sig selv (Vietnam-krigen er det sidste absurde eksempel) [...]' (FF 139)

Bemærkningen kan have en fornuftig mening, hvis den sigter til Vietnam-krigens økonomiske betydning for en del af USA's kapital, men det er ikke sandsynligt, at det er tanken, snarere er pointen, at 'det vestlige menneske' ikke har løst sine indre konflikter og derfor 'har for vane' at udkæmpe ydre konflikter, en tankegang som umiddelbart fører videre til en forestilling om hver enkelts ansvar for verdenssituationen. Således skriver Villy Sørensen mere alment:

'Spørgsmålet om krig og fred er jo både et psykologisk og et sociologisk spørgsmål, og der er ingen grund til at tro at der skulle være større forskel mellem årsagene til et menneskes og til et samfunds krigeriskhed.' (HE s. 27)

Og lidt længere fremme:

'Netop fordi den krigeriske holdning udspringer af de uforløste private konflikter, og fordi der er noget uhyre tilfredsstillende i at angribe andre for det man ikke selv kan klare, er krigen i grunden mere populær end freden.' (s. 27-28)

Det er karakteristisk, at Villy Sørensen ingen anstrengelser gør sig for at undersøge de økonomiske og politiske sammenhænge f.eks. Vietnam-krigen er betinget af, 'analysen' forbliver på det spekulative plan, hvor dens resultat omtrent hver gang er givet på forhånd: ondet skyldes indre forhold eller er i overensstemmelse med indre forhold, og disse hænger igen sammen med manglende selverkendelse, en utilstrækkelig udvikling af personligheden - og her kommer så kunsten og filosofien ind $\mathrm{i}$ billedet og stiller den enkelte over for kravet om at se sin egen dårligdom i øjnene:

'På trods af alle de upersonlige faktorer, som menneskene altså kun har begrænset magt over, skal man ikke undervurdere de psykologiske faktorers betydning: at menneskene kun har begrænset magt over deres magtmidler, kunne jo skyldes, at de kun 
har begrænset magt over sig selv.' (HE s. 63)

Og det er netop kunstnerne, der kan se dårligdommen og dermed hjælpe til overvindelse af den:

'Kunstnerne, der hævder at give udtryk for deres tids konflikter, når de beskriver deres egne, må selvfølgelig mene, at der er en organisk forbindelse mellem de enkelte samfundsmedlemmers holdning og hele samfundets tilstand. [...] Den kendsgerning, at de 'positive' kunstnere gerne er slette kunstnere, kunne tyde på, at de slette kunstnere netop er dem, der ikke føler en umiddelbar sammenhæng mellem grusomheden i den enkelte og grusomheden $\mathrm{i}$ hele samfundet.' (HE s. 64-65)

I denne tankegang går identifikationen mellem det enkelte menneske og menneskene, i dette tilfælde 'samfundet', igen, og denne identifikation er overhovedet forudsætningen for forestillingen om kunstneren som almenhedens repræsentant uden videre. Der er således den nøjeste sammenhæng mellem Villy Sørensens filosofiske tankegang og hans kunstsyn: i begge tilfælde viger han uden om en refleksion over de konkrete forhold i samfundet, formidlingen mellem de forskelligt (klassemæssigt forskelligt) placerede enkelte og den samfundsmæssige helhed på den ene side, og kunstnernes samfundsmæssige placering på den anden side. Den generelle tankeform er identifikationen: enkeltmennesket, Mennesket som sådant, samfundet, kunstneren: almenheden etableres direkte uden om den konkrete samfundsmæssige realitet. Derfor er der heller ikke meget at sige om dette almene, det bliver om ikke en 'indre stum almindelighed', så dog en sammenføjning af abstraktalmene teser.

\section{Velferdsstaten og friheden}

Diskussionen af forholdet mellem Kierkegaard og Marx mundede ud i, at nok var Kierkegaard 'ensidig' i sin tid, men det samme var Marx, dog sådan, at Marx' 'ensidighed' ville blive stadig mere tydelig, jo mere de ydre begrænsninger i friheden ville forsvinde. $\mathrm{Og}$ Villy Sørensen synes at gå ud fra, at de i det væsentlige er forsvundet i 'velfærdsstaten'. Det kunne han dårligt mene, hvis han holdt sig til klasseforholdene i Marx' analyse og i 'velfærdsstaten', men det gør han netop ikke.

'I sidste instans er marxismen også en psykologisk teori - som aldrig blev udformet; arbejdsdelingen krævede af Marx at kun den 
økonomiske side af teorien blev udformet, fordi de økonomiske problemer var de mest påtrængende. $\mathrm{Nu}$ falder det naturligt at lægge lige så stor vægt på de psykologiske, eftersom den menneskelige frigørelse er blevet problem i de samfund, hvor menneskene har fået flere friheder og mere fritid.' (ØF s. 24)

Og da er det ikke mindst Kierkegaard, der får aktualitet:

'Kierkegaards problemstilling bliver naturligvis særlig påtrængende hvis der faktisk ikke er noget, der i det ydre stiller sig i vejen for friheden; det kan derfor ikke undre at hans filosofi var længere om at gøre sig gældende end den marx'ske: dens succes forudsætter det sociale fremskridt, som Kierkegaard selv ikke kerede sig om, først når de økonomiske problemer trænges i baggrunden, trænger de psykologiske og åndelige sig i forgrunden, sammen med den åndløse 'masse', som Kierkegaard allerede advarede imod.' (HE s. 91)

Denne masse består af 'enkelte, der ikke er sig selv' (HE 236), men som har muligheden for at blive det, samtidig med at de viger tilbage for det:

'Velfærdsstatens store fare, ikke uden videre dens 'skyld', er at mennesker i den lader sig friste til at suspendere deres egen besværlige personlighed, netop fordi det $\mathrm{i}$ velfærdsstaten muligvis $\mathrm{i}$ modsætning til alle andre former for samfund, er muligt at klare sig ganske godt helt uden personlighed, man kan jo altid gøre nytte og få sin løn som fagmand og funktionær'. (Dd s. 221)

Så længe den ydre frihed ikke er til stede holdes i det mindste frihedstrangen i live, men når den ydre frihed er opnået, så opstår problemet:

'Er demokratiet opstået som en modstandsbevægelse mod de egoistiske og krigeriske kræfter i samfundet, er det for tidligt at proklamere dets sejr, når disse kræfter holder hinanden $\mathrm{i}$ balance $\mathrm{i}$ det ydre, modstandskampen må fortsæt tes i det indre.' (HE s. 109).

Her er det igen den oven for nævnte analogi mellem det indre og det ydre, der tilslører, hvad der i realiteten er tale om: filosoferen over et kapitalistisk samfund med en vis statsindblanding og et vist relativt højt leveniveau. Her slutter for Villy Sørensen fremskridtet i det ydre, mens kampen for personligheden kommer i centrum (dette er hovedlinjen $\mathrm{i}$ betragtningerne, ind imellem kan der godt dukke andre tankegange op, men den nævnte er den centrale).

Åndsarbejde har ifølge sit væsen affinitet til politisk radikalisme, mener Villy Sørensen (HE s. 105), og da han selv er talsmand for åndsarbejderne trækker han Hørup frem som eksempel på en 
politiker, der kæmpede for at forvandle massen til personligheder:

'Sit opflammende 'I er den offentlig mening' måtte han til en begyndelse rette til dem, der enten slet ingen mening havde eller som havde overtaget de dannedes mening om at de var 'udannede'. (HE s. 170 )

For Villy Sørensen er imidlertid forvandlingen af 'den passive masse' til 'aktive personligheder' (HE s. 171) tillige en ophævelse af deres politiske orientering ud fra klasseinteresser. Vælgerne og politikerne bør ikke lade sig styre af økonomiske interesser, men lade helhedens problemer være afgørende:

'Er der, midt imellem to modsatte udviklingstendenser (hen imod formynderstat og popdemokrati) en tredje mulighed, en mulighed for virkelig at lade samfundsmedlemmerne vælge frit uden at overlade alt for meget til tilfældigheden? At et menneskes valg kan forudsiges, vil ikke sige at der slet ikke er tale om et valg: det vælger jo mere frit, jo mere logisk dets valg kan udledes af dets egne forudsætninger. Foreløbig er et menneskes politiske baggrund langt mere afhængig af dets 'tilfældige' sociale baggrund end af dets egen personlighed: jo mere miljøforskellene træder tilbage, jo mere vil de psykiske forskelle blive udslaggivende. De politiske konsekvenser af en mere radikal psykisk frigørelse må blive et valg, der ikke så meget er determineret af økonomiske interesser som af personlig interesse i dette ords oprindelige betydning. Et valg af personer, der selv er mere personligt end økonomisk interesserede i de fælles problemer: et mere individuelt valg af mindre partibundne personer, som er lige langt fra at være formyndere og funktionærer.' (FF s. 304-5) Denne politiske utopi er fuldstændig løsrevet fra, eller ønsker $i$ det mindste at løsrive sig fra de sociale realiteter: det er en drøm om en vælgerskare af økonomisk desinteresserede oplyste personligheder, der vælger en skare af lige så økonomisk desinteresserede og endnu mere oplyste politikere, som gennem fordomsfri og desinteresseret debat kan finde frem til løsninger, der tager helheden i betragtning. Det er kort sagt drømmen om en borgerlig offentlighed, sådan som Hebermas skildrer idealet, men det er samtidig en projektion af den egne situation ud over hele det politiske liv, den egne situation forstået som hævet over klassemodsætningerne. 


\section{Kunsten, angsten og demokratiet}

I en sådan utopi tilkommer der kunstnere og intellektuelle en central plads. Demokratiet må bygge på åndelige værdier (HE 109), og dem er åndsarbejderne naturligvis de nærmeste til at forvalte og udbrede.

'Da kunst er frigørelse, følger det af dens væsen at den kun kan vurderes indforstået af den, der har gennemgået dens frigørelsesproces, hvad de fleste viger tilbage for, fordi det er ubehageligt.' (HE s. 100)

Og denne frigørelsesproces er identisk med den personlighedsdannelse, som er forudsætningen for den fulde udvikling og bevarelse af 'demokratiet'. Angsten er forudsatningen for at personlighedsudviklingen sættes igang og:

'I den moderne kunst kan mennesker finde den angst udtrykt som de selv har i sig, men som de måske først bliver sig bevidst når de stilles over for kunstværket, så de tror det er kunsten der fremkalder angsten og anklager den for at være altfor dyster og livsfjendsk.' (HE s. 19)

Det er derfor en misforståelse at tro, at der skulle være noget galt med den moderne kunst, det er tværtimod dens publikum det er galt fat med, og det er fatalt for demokratiet, som derfor må gøre noget for udbredelsen af den moderne kunst:

'At folket nødig vil bekvemme sig til at beskæftige sig med kunst, beviser ikke at der er krise i kunsten, men snarere at der er krise i folket, og det skyldes ikke at kunstnerne ikke har taget tilstrækkeligt hensyn til folket, men at kulturpolitikken ikke har giort det.' (HE s. 101)

Selv om politikerne - som Hørup - også kan bidrage til at opdrage folket til personligheder, så er det dog kunsten, der må stå i centrum, eftersom den udvikling kommer til syne i kunsten 'som ethvert menneske gennemgår, den stræben mod helt at blive sig selv - som rigtignok de færreste formår at fuldbyrde' (HE s. 195), og eftersom 'Intet andet sted møder man et så koncentreret udtryk for det der foregår inderst inde i en selv, og intet andet sted får man en så kraftig hjælp til at blive rykket ud af den lumre hule af subjektivitet som man sidder og skumler eller hygger sig i til daglig.' (s. 189-90)

Den kunst, der her er på tale, er den moderne kunst, som Villy Sørensen undertiden kalder modernismen, hvormed han mener kunsten fra ca. de sidste 100 år, hvor den har været i opposition til samfundet, og opposition til 'samfundet' vil sige opposition til 
flertallet.

Der er kun to alternativer til denne kunst for Villy Sørensen, og de kan egentlig komme ud på ét: popkunsten og socialrealismen, som begge er skønmalende og problemfortrængende. Socialrealismen hører hjemme i de kommunistiske samfund, hvor problemerne så at sige er afskaffet ved lov ('kommunismen dekreterer at selvafvigelsen er ophævet', HE s. 95, 'ophævelsen af sociale forskelle fører logisk til forbud mod forskellighed' s. 18), popkunsten hører hjemme i velfærdsstaten, hvor den repræsenterer faren for tilbagefald eller slap forbliven i det uvæsentlige. Den 'progressive eller kommunistiske anskuelse' lyder: 'at kunstnere er særlig sunde livsbekræftende mennesker, der skal skildre det skønne og skabe positive helte, thi i et godt samfund er menneskene naturligvis lige så gode som de af naturen er. Og skildrer en kunstner noget i samfundet som er slet, er det ham der er noget i vejen med, og så bør han forbydes'. Tilbage står så - for Villy Sørensen - kun modernismen, den mest upopulære kunst, som er den egentlige folkelige kunst, eftersom det er den folket har brug for i sin personlighedsudvikling. Det var denne kunstforståelse, der gav baggrund for en del af indlæggene under debatten om statens kunstfond i midten af tresserne. Som kunstnerne repræsenterer åndsarbejderne $\mathrm{i}$ almindelighed den væsentlige indsigt:

'De intellektuelles opgave i samfundet er med et -skarpt intellektuelt blik at gennemskue gamle ting, der er forkerte, og at opdage nye ting, der er mere rigtige. Det ville derfor være for meget forlangt, at de just skulle være de allermest populære samfundsmedlemmer. Folket foretrækker gerne det gamle, som det har vænnet sig til, og magthaverne er altid på vagt over for det nye [...]' (HE s. 40)

Ikke desto mindre er det altså efter Villy Sørensens opfattelse på disse intellektuelle - og på politikerne - demokratiet beror: 'Andsarbejdernes opgave er at opdrage folket til saglighed, men er politikernes opgave ikke den samme.' (s. 107-8)

Overvejelserne over demokratiet munder altså i sidste instans ud i forestillingen om en alliance imellem progressive politikere og åndsarbejdere, og det er netop den samme tanke, som Viggo Kampmann gav udtryk for omkring 1960, ligesom det var den socialdemokratiske kulturpolitiks formål at skabe økonomisk grundlag for udviklingen af den moderne kunst. Imellem Villy Sørensen og staten var der således ingen videre grund til gnidninger.

Midt i velfærdsperioden mellem den kolde krigs afslutning og 
klassekampens opsving i slutningen af tresserne formulerede Villy Sørensen med stor præcision de kulturelt orienterede intellektuelles selvforståelse, som holdt liv i en række af halvtredsernes intellektuelle positioner. Først i slutningen af tresserne begyndte et alternativ til disse positioner langsomt at udvikle sig. Men det er en anden historie.

\section{Note:}

Et tredje kapitel om overgangen fra den kolde krig, nemlig om SFs dannelse, kan lases i Socialistisk Politik nr. 6 under titlen: Den fremskridtsvenlige offentlighed.

Poul Henningsen er citeret efter Kulturkritik I-IV, udg. Bay \& Harsløf, Rhodos 1973.

Villy Sørensen er citeret efter følgende skrifter: Digtere og Damoner (DD), Gyldendal (som de falgende) 1959, Hverken-Eller (HE), 1961, forord til Kierkegaard: Begrebet Angst (BA), 1961, forord til Marx: Økonomi og fllosofi (ØF), 1962, Mellem fortid og fremtid (FF), 1969.

Udviklingen fra tresserne til halvfjerdserne har jeg skitseret $\mathrm{i}$ indledningen til antologien Linjer i nordisk prosa 1965-75. Danmark 1977, samt i artiklen 'Det gamle nye venstre, det nye nye venstre - og det nye gamle venstre' i Hug, Ord \& Bild og Kontrasts fallesnummer om Venstrebevægelsen i Skandinavien, 1977.

Artiklen her er, bortset fra indledningen, skrevet i 1976 og angår kun tiden op til 1968. I mellemtiden har Villy Sørensen som medforfatter til Opror fra midten endnu en gang bidraget til en udkrystallisering af kulturelt-politiske positioner, dennegang under indoptagelse af en god del af det nye venstres samfundskritik. Jeg skal ikke diskutere alt dette $\mathrm{i}$ en note, men jeg kan henvise til Torben Hviid Nielsens artikel "'Opror fra midten' eller Utopiens hverken-eller» (Socialistisk Politik nr. 9, 1978). 